\title{
Şehirden Kırsal Alanlara Ziyarette Köyün Çekici Faktörlerinin Analizi: Bağlıca Köyü Örneği (Sinop/Boyabat)*
}

\author{
Analysis of the Attractive Factors in Visiting Rural Areas: The Case of Bağlıca Village \\ (Boyabat/Sinop)
}

\author{
Müjde AYDOĞDU' ${ }^{10}$, Muzaffer BAKIRCI ${ }^{2}$ [D
}

${ }^{1}$ İstanbul Üniversitesi, Sosyal Bilimler Enstitüsü Coğrafya Anabilim Dalı, İstanbul, Türkiye

${ }^{2}$ İstanbul Üniversitesi, Edebiyat Fakültesi Coğrafya Bölümü, İstanbul, Türkiye

ORCID: M.A. 0000-0002-1452-7730; M.B. 0000-0002-4848-3086

\section{ÖZ}

Göç, insanlık tarihi kadar eski ve insanoğlunun yeryüzündeki varlığı devam ettiği müddetçe de hiç kuşkusuz devam edecek mekânsal değişim ve etkileşimin en önemli unsurlarından birisidir. Türkiye, özellikle 1950'li yıllarda başlayan ve 1980'li yıllarda daha yüksek seviyelere ulaşan kırsal alanlardan şehirlere doğru yoğun bir göçü yaşandığı coğrafi bir mekân durumundadır. Ancak göçe konu olan insanların büyük bir bölümünün göç ettikleri kırsal yerleşmelerle bağlarının tamamen kopmadığı görülmektedir. Bu çalışmanın kapsamını geçmişten itibaren şehirsel alanlara göç vermiş olan Sinop ili Boyabat ilçesine bağı Bağlıca köyü oluşturmaktadır. Çalışma, bir yanda Bağlıca köyünden göç etme nedenlerinin belirlemeyi hedeflerken, diğer taraftan göç edenlerin sonraki dönemlerde köylerini ziyaret etmelerinde etkili olan faktörleri analiz etmeyi amaçlamaktadır. Çalışmanın temel veri setini, Bağlıca köyünden kendisi ya da ailesi göç etmiş kişilerle yapılan 17 soruluk anket sonuçları oluşturmuştur. Toplam 121 kişinin katıldığı anketin $115^{\prime} i$ geçerli kabul edilmiştir. Elde edilen sonuçlara göre; göç edenlerin yaklaşık \%82'si İstanbul'a göç etmiş ve göç etme nedenlerinin en önemlisini ekonomik faaliyetler oluşturmuştur. Ankete katılan kişilerden \%52'si köyü yılda en az iki kez ziyaret etmekte ve \%45'i köye gittiğinde 15 gün kalmaktadır. Toplam 115 kişiden 73 'ü ileride köye temelli olarak dönmeyi düşünürken, ankete katılanların 49'u emekli olunca köye dönmek istediklerini ifade etmişlerdir.

Anahtar kelimeler: Göç, Köy Ziyaretleri, Bağlıca Köyü

\section{ABSTRACT}

Turkey is a geographical place where there has beenan intense migration from rural areas to cities, particularly starting from the 1950s and reaching higher levels in the 1980s. However, it is seen that most of the people who migrated have not completely lost their ties with the rural settlements from which they have migrated. The scope of this study consists of Bağlıca village of the Boyabat district of Sinop province which has been a source ofmigration to urban areas since the past. The study intended to determine the reasons for the migration from Bağlıca village and aimed to analyze the factors that have influenced the migrants to visit their villages in the following periods. The basic data of the study consisted of the results of a 17-question survey. A total of 121 people participated in the survey and 115 were accepted as valid. According to the results obtained, $82 \%$ of the migrants migrated to Istanbul and economic activities were the most important reasons, $52 \%$ of the survey participants visit the village at least twice a year and $45 \%$ stay for 15 days.While 73 were planning to return to the village in the future, 49 of the participants stated that they want to return when they retired.

Keywords: Migration, Visiting the Village, Bağlıca Village

* Bu çalışma; 20-22 Haziran 2019 tarihinde İstanbul Üniversitesi'nde gerçekleştirilen I. Uluslararası İstanbul Coğrafya Kongresi'nde sunulan sözlü bildirinin genişletilmiş halidir.

Başvuru/Submitted: 13.09.2019 • Revizyon Talebi/Revision Requested: 06.02.2020 • Son Revizyon/Last Revision Received: 17.02 .2020 • Kabul/Accepted: 15.03 .2020 • Online Yayın/Published Online: 20.04 .2020

Sorumlu yazar/Corresponding author: Müjde AYDOĞDU / mujde.5758@gmail.com

Atıf/Citation: Aydogdu, M., Bakirci, M. (2020). Analysis of the attractive factors in visiting rural areas: The case of Bağlıca village (Boyabat/Sinop). Cografya Dergisi. Advance online publication. https://doi.org/10.26650/JGEOG2019-0035 


\section{EXTENDED ABSTRACT}

Turkey is a geographical place where there has been an intense migration from rural areas to cities, particularly starting from the 1950s and reaching higher levels in the 1980s.Both the unused labor force created by mechanization in agriculture and employment opportunities created by industrial activities concentrated in urban areas, played an active role in the migration of this rural population to urban areas.

While economic reasons are largely determinativein migrating from rural areas to urban areas, many other factors such as moving away from the traditionally equipped environments of the villages, benefitingmore from socio-economic and physical opportunities of the cities and security problems, contributed to the mobility of this population. Aspects of migration in Turkey occurred mainly to the major cities where the industrial activities are intensively located such as Istanbul, Ankara, Izmir, Adana and Bursa.

The population that migrated from rural areas to the cities affected the spatial structure and social formation of the city andthey too wereaffected by it.Moreover, even if they face adaptation to new living spaces for economic, social, political or other reasons, it is seen that most of the people who migrated have not completely lost contact with the places from which they migrated. While these communities try to adapt to urban life, they also try to keep the culture of the regions they migrate to.These efforts, which also aim to transfer their original cultural values to future generations, sometimes take the form of conducting some activities in the city where they live and often take the form of visiting their village.

The scope of this study consists of Bağlıca village of the Boyabat district of Sinop province which hasbeen a source of migration to urban areas since the past. While the village had755 inhabitants in 1965, there has been a decrease in the general population since that date and also since the 2000s, and the total population has been below 300.As of 2018, the total population of the village is 283 . Bağlica Village is $5 \mathrm{~km}$ away from Boyabat district center and it is located on a plain. The main economic activity of the village is agriculture and animal husbandry.Gökırmak river which passes through the village plays a major role in paddy cultivation.

The study intended to determine the reasons for the migration from Bağlica village and aimed to analyze the factors that have influenced the migrants to visit their villages in the following periods. The main question of the research is whether the villagers want to return to their villages in the future. The other questions are the conditions under which the villagers want to return, and if they do, what economic activities do they want to carry out in the village.

The basic data set of the study consisted of the results of a 17-question survey that was conducted with persons who had migrated from Bağlica village.A total of 121 people participated in the survey and 115 were accepted as valid.The questions posed in the questionnaire were formed in four stages. The first part of the questionnaire aims to reveal the basic characteristics of the participants, the second part is to determine the migration processes from the village, the third part is to question the main reasons of the visits to the village and the fourth part is to determine the basic expectations and targets related to the village in the future.

According to the results obtained,the age range of the survey participants ranged from 18 to 79 years old, 67 of them were male and 48 were female.Again, 91 of the respondents were born in Bağlıca village and migrated to other cities for various reasons.Approximately $82 \%$ of migrants migrated to Istanbul and the most important reason for migration was economic conditions.52\% of the survey participants visit the village at least twice a year and $45 \%$ of them stay for 15 days when they visit the village. The biggest contributoramong the reasons for visiting the village was for festivals (bayram) and summer holidays, family visits and cemetery visits. While 73 of a total of 115 people were planning to return to the village on a future basis, 49 of the survay participants stated that they wanted to return to the village when they retired.The number of people who want their children to return to the village in the future is 72 . Thesehavealready led their lives in cities, but shows that the majority, not only themselves, but also their children, are eager to return to their birthplace in the future. 


\section{GİRISs}

İnsanlık tarihi kadar eski olan göç, basit bir tanımlaması yapılamayan ve tek bir bilim dalının prensipleri ve kurallarına göre açıklanamayan oldukça çok bileşeni bulunan bir yapıdır. Bu özelliği nedeniyle de birçok bilim dalının çalışma alanına girer ve bunların önermeleri, formülleri ve tanımlamalarından faydalanılarak açılanabilir. Yapısı itibariyle; sosyoloji, tarih, coğrafya, hukuk gibi sosyal bilimleri içine alırken, ekonomi, ekoloji, istatistik gibi sayısal disiplinlerin de içerisinde yer almakta, bu çalışmalara konu olmaktadır.

Tarihsel süreç içerinde insanlar çeşitli nedenlerle bulundukları bölgelerden ayrılarak farklı yer ve bölgelere göç etmişlerdir. Göçün kuramsal anlamda temellendirilmesinde Ravanstein'in çalışmaları öncü kabul edilmektedir. 1889 yılında yazdığı "The Laws of Migration" adlı çalışmasında Ravenstein, insanların itici ve çekici etmenlerden yola çıkarak başka yer veya bölgelerdeki iş imkânlarının çekiciliği ile hareket ettiklerini ileri sürmüştür. Nitekim bu düşünce 21 . yüzyılda da hâlâ güncelliğini korumaktadır (Sirkeci ve Cohen, 2015, s. 10).

Tarih sahnesinde insanlığın var olduğu ilk zamanlardan bu yana yer değiştirme hareketi olarak ifade edilen göç, kişilerinin hayatlarının gelecekteki bölümünün tamamını veya bir kısmını sürdürmek üzere kalıcı veya geçici olarak bir yerleşim biriminden diğerine yerleştirmek kaydıyla yaptığı coğrafiyer değiştirme hareketidir (Akkaş ve Sevim, 2017, s. 440; Tekeli ve Erder, 1978, s. 17; Doğanay, 1994, s. 165; Sertkaya Doğan, 2019, s. 16).

Göçlerin niteliği ve içeriği zaman içerisinde sürekli olarak değişim göstermiştir. İlk aşamalarda iklim koşulları, savaş veya kıtlık gibi nedenlerle oluşan bu hareketler, zamanla yerini sosyal, kültürel, siyasi veya eğitim gibi sebeplere bırakmıştır (Dönmez Kara, 2015, s. 11; Toros, 2008, s. 9; Çağlayan, 2015, s. 193; Özer, 2004, s. 11; Akkayan, 1979, s. 5).

Birçok çalışmada göçle ilgili olarak farklı sınıflandırmalar yapılmaktadır. "Örneğin "Fichter göçü genel olarak zorunlu ve gönüllü olmak üzere ikiye ayırırken, Peterson göçü; ilkel göç, kontrollü göç, serbest göç ve zorunlu göç şeklinde bir ayrım yapmıştır (Kurt, 2006, s. 150). Mekânlar arası hareketlilik bakımından ise göç, ülkelerin büyüklüğü, ekonomik kalkınmışlık düzeyi ve yerleşme tarihlerine bağlı olarak; kırlardan şehirlere, kırlardan kırlara, şehirlerden kırlara ve şehirlerden şehirlere doğru olmak üzere dört gruba ayrılmaktadır (Tümertekin ve Özgüç, 2011, s. 317).
Göçler köylerin geleneksel niteliklerle donatılmış ortamlarından uzaklaşmak, kentin sosyo-ekonomik ve fiziksel olanaklarından daha fazla yararlanmak ve güvenlik sorunları gibi başka birçok faktörden dolayı nüfus hareketliliğinin yaşanmasına katkı sağlamaktadır. Türkiye'de özellikle 1950'lerde başlayan ve 1980'li yıllarda daha da yoğunlaşan göçler, sanayi faaliyetlerin yoğun şekilde yaşandığ İstanbul, Ankara, İzmir, Adana ve Bursa gibi büyük şehirlere doğru gerçekleşirken, son y1llarda ise özellikle daha önce göç veren yerlerin, göç alan yerlerden gelen insanların geri dönmesini kapsayan tersine göç hareketleri de başlamıştır (Yürüdür, 2008; Yazıc1, 2012; İslamoğlu, Yıldırımalp ve Benli, 2014). Kırdan ayrılan ve şehirlerde toplanan insanlar, şehirsel yaşama ayak uyduramayıp şehirsel değerleri benimseyemeyince kır ile şehir hayatı arasında kalmakta sonuç olarak da kırsal bağlarını daha güçlü tutması sonucunu doğurmaktadır (Aktaş, Aka ve Demir, 2006, s. 53).

Türkiye'de, özellikle 1950'lerden sonra kırsal alanlardan kentlere doğru göç, hızlı bir kentleşmeyi de beraberinde getirmiştir. Cumhuriyetin ilanından sonra 1927 yılında yapılan ilk nüfus sayımında kırsal alanlarda yaşayan nüfusun oranı $\% 75,8$ iken, bu oran 1950 'de $\% 75^{\prime}$ e, 1980'de \%56,1'e, 2000'de $\% 35,1$ 'e, 2010 'da $\% 23,7$ 'ye, 2013'te $\% 8,7$ 'ye, 2014 'te $\% 8,2$ 'e ve 2018 yılında \%5,2'lere düşmüştür (DİE, 1927-2000; TUİK, 2019). Ancak 2013 yılından itibaren kırsal nüfus oranında meydana gelen belirgin azalma doğal süreçte meydana gelen bir oransal değişimden dolayı olmamış, bir idari tasarrufun sonucunda gerçekleşmiştir. 6360 sayılı yasayla büyükşehir statüsüne getirilen 30 ilde yer alan tüm köyler mahalle olarak kabul edilmiş ve bu yerleşmelerde yaşayan nüfusu da şehir nüfusuna dâhil edilmiştir.

\section{AMAÇ VE YÖNTEM}

Bu çalışma, Sinop ili Boyabat ilçesine bağlı Bağlıca köyünden göç etmiş olanların göç etme nedenlerini belirlemeyi hedeflerken, aynı zamanda da göç edenlerin sonraki dönemlerde köylerini ziyaret etmelerinde etkili olan faktörleri analiz etmeyi amaçlamıştır. Köylülerin gelecekte köylerine temelli olarak dönmek isteyip istemedikleri, istiyorlarsa hangi şartların uygun hale gelmesiyle bu geri dönüşü gerçekleştirecekleri ve döndükleri takdirde köyde hangi ekonomik faaliyetleri yürütmek istedikleri gibi hususlar araştırmanın cevap aradığı diğer soruları teşkil etmiştir.

Çalışmanın temel veri setini, Bağlıca köyünden kendisi ya da ailesi göç etmiş kişilerle yapılan 17 soruluk anket sonuçları oluşturmuştur. Ankete katılım web üzerinden gerçekleştirilmiş olup, katılım sağlayanlar anket formuna online olarak 
ulaşabilmişlerdir. Bilimsel araştırmalarda bir veri toplama aracı olarak kullanılan web tabanlı anket metodu, geleneksel anket metotlarına göre zaman, maliyet ve harcanan emek açısından daha kullanışlı görülmektedir (Karakoyun ve Kavak, 2008, s. 130). Örneklemin seçilmesinde ailesinin ya da kendinin Bağlıca köyünde doğmuş olması ve herhangi bir zamanda buradan göç etmiş olması temel koşul kabul edilmiştir. Olasılıklı (rastlantısal) Örneklem metodunun uygulandığı anket sonuçlarının değerlendirilmesinde SPSS 17.0 paket programı kullanılmıştır.

Toplam 121 kişinin katıldığı anketin 115'i geçerli kabul edilmiştir. Ankette yöneltilen sorular dört aşamalı olarak biçimlendirilmiştir. Anket sorularının birinci bölümü ankete katılarından temel niteliklerini ortaya koymayı hedeflerken, ikinci bölümü köyden göç etme süreçlerini tespit etmeyi, üçüncü bölümü köye yapılan ziyaretlerin temel gerekçelerinin sorgulamayı ve dördüncü bölümü ise gelecekte köyle ilgili temel beklenti ve hedeflerini belirlemeyi amaçlamıştır.

\section{3. ÇALIŞMA ALANININ LOKASYON VE GENEL ÖZELLÍKLERİ}

Sinop ili Boyabat ilçesi idari sınırları içinde yer alan Bağlıca Köyü, Sinop merkeze 97 km, Boyabat'a ise 5 km uzaklıkta yer almaktadır (Şekil 1).

Bağlıca köyü ve yakın çevre fiziki coğrafya özelliklerine batığımızda, Gökırmak’ın hemen kuzey kıyısında düzlük bir alanda kurulduğunu görmekteyiz. Köyün güney ve batı kesimlerinde ova alanı yer alırken, kuzey kesiminde ise hafif eğimli tepelik bir alan yer almaktadır. Tarım arazilerinin yoğun olarak yer aldığı Bağlıca köyü çevresinde, yamaç sahaları ise doğal bitki örtüsüne ayrılmıştır (Şekil 2).

1965 yılında 755 nüfusa sahip olan Bağlıca köyünde, bu tarihten itibaren nüfusta genel olarak bir azalma eğilimi söz konusu olmuştur. 2000'li yıllardan itibaren ise toplam nüfus 300'ün altında seyretmiştir. 2019 yılı itibariyle köyün toplam nüfusu 255 'tir (Tablo 1 ve Şekil 3).

TUİK verilerine göre köyün nüfusu her ne kadar 200'lerde olsa da, yaz aylarında özellikle Ağustos ve Eylül ayının başında 600'leri bulmaktadır. Bunun ise en önemli nedeni köylülerin yaz tatillerini köyde geçirmek istemeleri ve çeltik hasadını beklemeleridir.

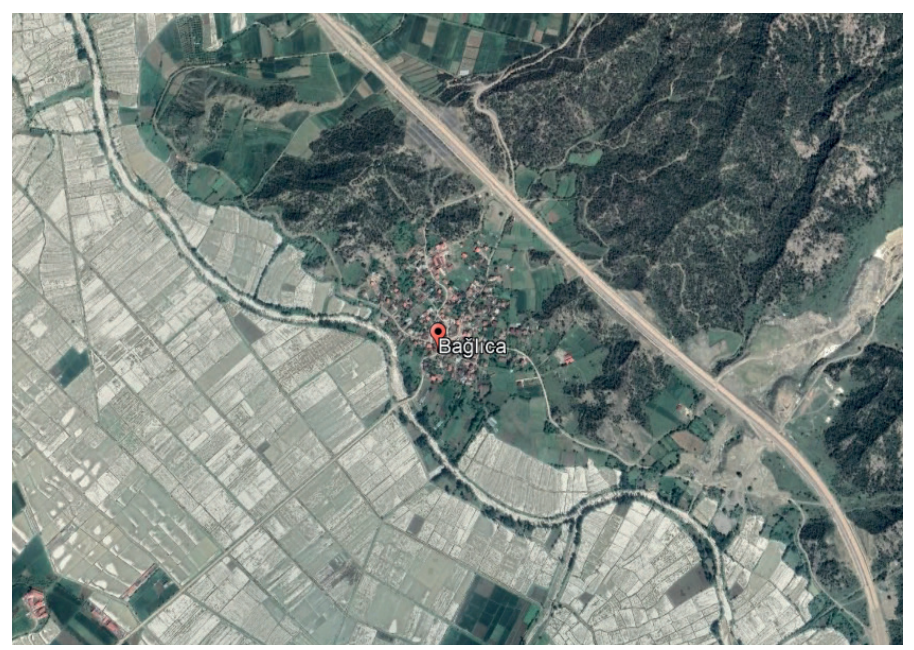

Şekil 2: Bağlıca Köyü Topografik Özellikleri (Google Earth, 2019). Figure 2: Topographic Characteristics of Bağlıca Village (Google Earth, 2019).

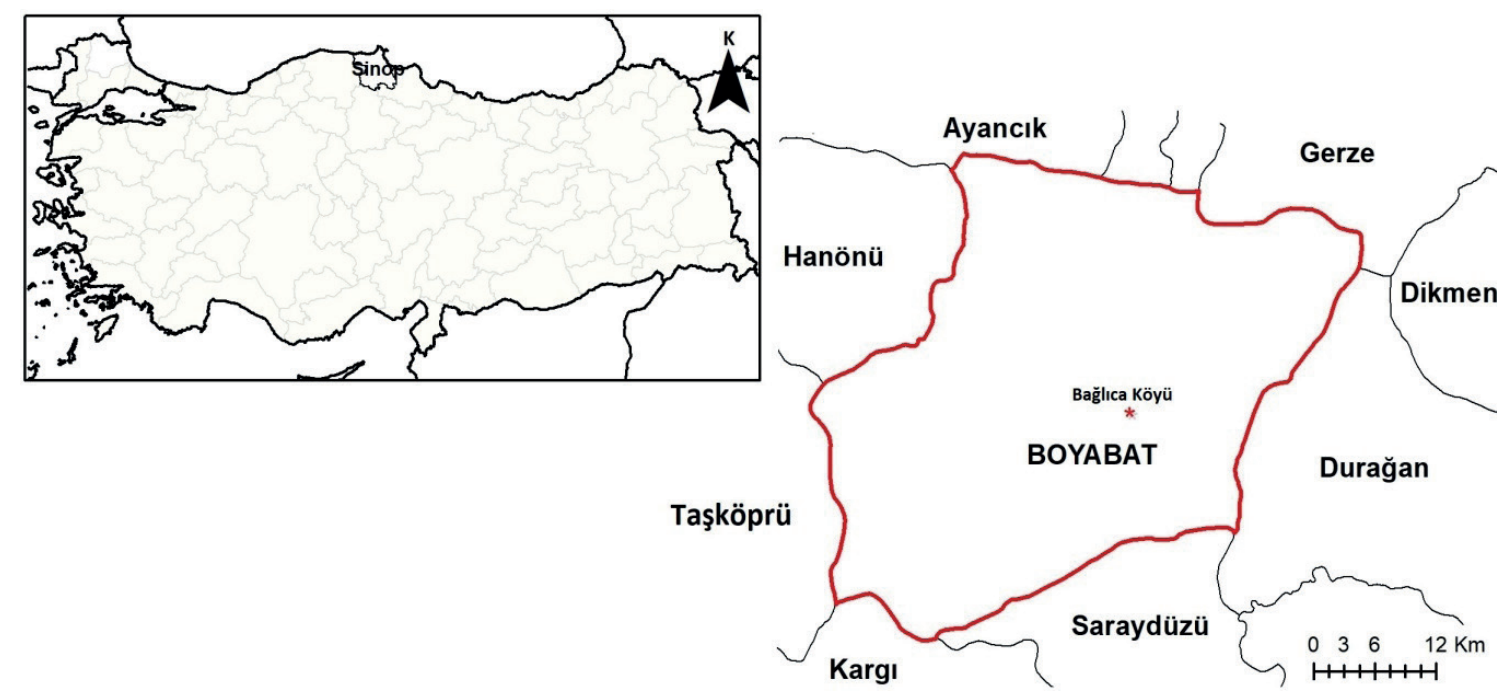

Şekil 1: Bağlıca Köyü Lokasyon Haritası.

Figure 1: Location Map of Bağlıca Village. 
Tablo 1: Bağlıca Köyünde Nüfusun Yıllara Göre Değişimi (1935-2019). Table 1: Change of Population by Years in Bağlıca Village (1935-2019).

\begin{tabular}{cccc}
\hline Yıllar & Erkek & Kadın & Toplam \\
\hline 1935 & 195 & 204 & 399 \\
1940 & 215 & 208 & 423 \\
1945 & 251 & 234 & 485 \\
1950 & - & - & - \\
1955 & 303 & 300 & 603 \\
1960 & 349 & 358 & 707 \\
1965 & 391 & 364 & 755 \\
1970 & 327 & 361 & 688 \\
1975 & 326 & 339 & 665 \\
1980 & 310 & 359 & 669 \\
1985 & 301 & 346 & 647 \\
1990 & 256 & 298 & 554 \\
2000 & 158 & 163 & 321 \\
2007 & 131 & 144 & 275 \\
2010 & 119 & 135 & 254 \\
2015 & 111 & 115 & 226 \\
2019 & 121 & 134 & 255 \\
\hline
\end{tabular}

Kaynak: TUIK

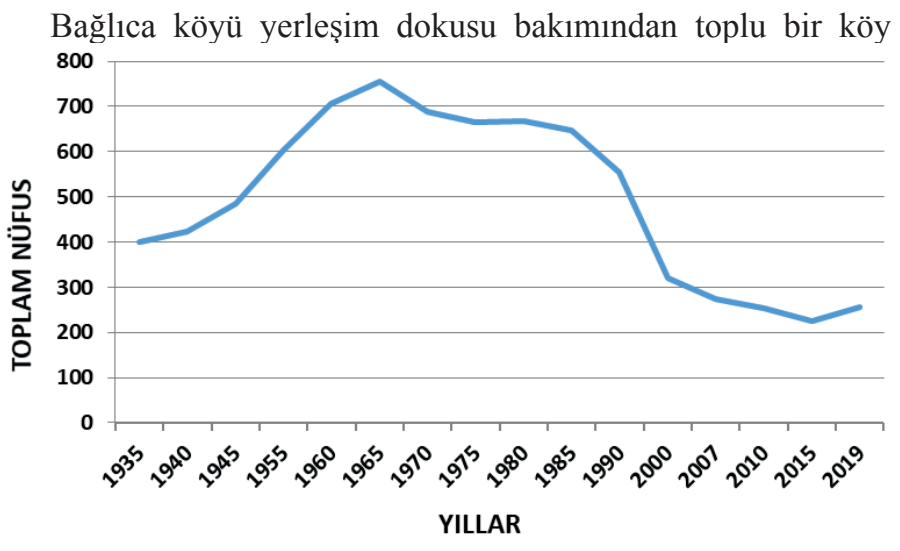

Şekil 3: Bağlıca Köyünde Nüfusun Yıllara Göre Değişimi (1935-2019). Figure 3: Change of Population by Years in Bağlıca Village (1935-2019).

karakteri göstermektedir. Bu bakımdan küme köy olarak değerlendirilebilir. Köyün merkezinde farklı yönlere doğru 1şınsal olarak uzanan yollar boyunca meskenler konumlandırılmıştır (Şekil 4).

Bağlıca köyünün Boyabat merkeze $5 \mathrm{~km}$ uzaklıkta olması köy için bir avantaj olsa da, köyün sosyal yaşam ve ticarethaneler konusunda eksik kalmasına neden olmuştur. Köyün en kalabalık olduğu dönemler olan 1980-1990 yılları aynı zamanda köydeki ticarethanelerin de en fazla olduğu yıllardır. Bu dönemlerde köyde değirmen, kalayc1, demirci, marangoz atölyesi ve bakkal varken bunlar 1990'lardan sonra özellikle köyden şehirlere doğru olan göçlerin artması, motorlu taşıtlarla şehri erişimin kolaylaşmasına bağlı olarak ihtiyaçların şehir merkezinde karşılanmasının imkân dâhiline girmesi dolaysıyla kapanmaya başlamış ve günümüzde hiçbiri kalmamıştır.

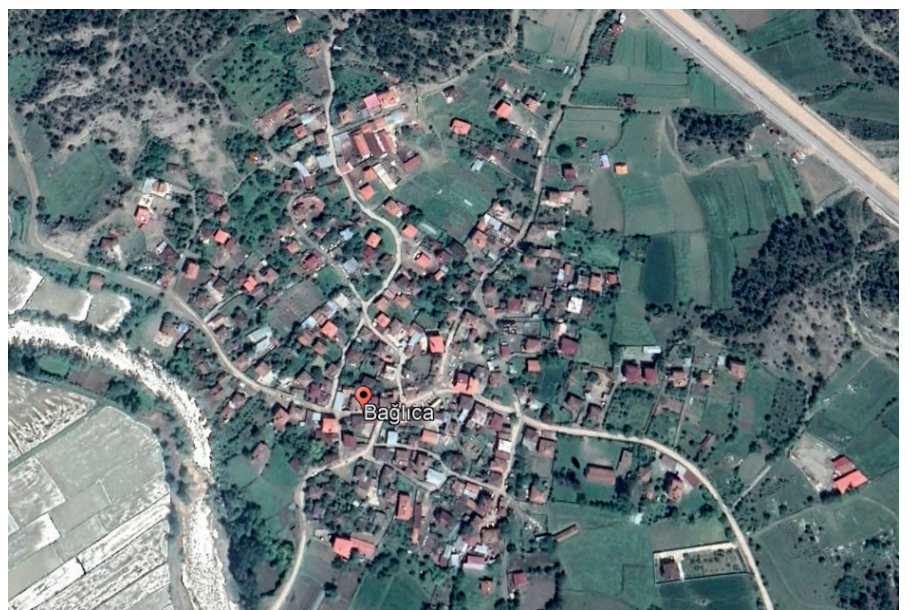

Şekil 4: Bağlıca Köyü Yerleşme Formu (Google Earth, 2019). Figure 4: Settlement Form of Bağlıca Village (Google Earth, 2019).

Hâlihazırda köyde eğitim ve sağlık konusunda herhangi bir hizmet sunulmazken, 1997 yılına kadar köyde 1 ebe görev yapmış ve ebe için bir lojman tahsis edilmiştir. Aynı şekilde 1990'lı y1llarda 1 ziraat mühendisi de köy için çalışmalar yürütmüştür. Günümüzde taşımalı eğitim sistemi uygulanan köyün, geçmişte eğitime hizmet eden ilkokul binası günümüzde köylünün etkinlik düzenlediği, toplu yemek verdiği hatta düğün ve nişan yaptığı bir mekân haline gelmiştir.

Köyün temel geçim kaynağı tarım ve hayvancılıktır. Buğday, arpa, yulaf vb. tarımsal ürünlerin yetiştirildiği ziraat sahaları 300 dönümü geçmektedir. Karaviran mevkiinde yer alan ve köyün merkezine yaklaşık 1 kmuzaklıkta olan bu tarlalar ihtiyaca göre köylüler tarafından ekilmekte ve üretim yapılmaktadır.

Tarımsal üretimde çeltik öne çıarken köyün içinden geçen Gökırmak çeltik tarımının yapılmasında büyük bir rol oynamaktadır. Köyün tarım topraklarında toplulaştırma projesi uygulanmış olup, modern tarım metotları uygulanmaktadır. Köyün çeltik ekimi için sahip olduğu tarım alanı 1500-1600 hektar arasındadır. Köyün girişinde Gökırmak kenarında yer alan çeltik tarlalarını sulamak için toplam 11 su kuyusu bulunmaktadır. İhtiyaca bağlı olarak DSİ tarafindan 1994 yılından itibaren açılan bu kuyulardan köylüler ücret ödemek şartıyla yaralanmaktadır.

Köyde çeltik tarımı ile alakalı bir sulama kooperatifi bulunurken, çeltik işleme ve pazarlamaya ilişkin herhangi bir birlik söz konusu değildir. Çiftçiler bireysel olarak çeltik ekimini yapmakta ve hasat etmekte, yine ürün satışını da bireysel olarak gerçekleştirmektedir. 


\section{BULGULAR}

Amaç ve yöntem bölümünde açılklandığ Bağlıca köyünden kendisi ya da ailesi göç etmiş kişilere web ortamında online olarak uygulanan 17 soruluk anket çalışması ile gerçekleştirilmiştir. Toplamda 121 kişinin katıldığı anketin 115'i geçerli kabul edilmiştir. Anket sonucunda elde edilen bulgular aşağıda detaylı olarak değerlendirilmiştir.

Anketin ilk sorusunu oluşturan "Yaşınız?" sorusuna 18 ila 79 yaş arasında değişenkatılımcılar cevap vermiştir. Ankete en fazla sayıda 38 ve 36 yaşlarındaki kişiler katılmıştır. Bu çerçevede katılanlardan 8'i 38, 7'si ise 36 yaşındadır. Diğer taraftan genel olarak anketekatılımın 30 ve 40 'lı yaşlarda yoğunlaşırken en az katılım 60 ve üstündekilerde gerçekleşmiştir (Şekil 5). Bu sonucun ortaya çıkmasında anket çalışmasının online olarak yapılmış olması etkili bir faktör olarak değerlendirilebilir.

Anketin 2. sorusunu "Cinsiyetiniz?" sorusu oluşturmaktadır. Ankete katılanların 67'si erkek 48'i ise kadındır. Bu da katılımın $\% 58$ 'inin erkeklerden \%42'sinin ise kadınlardan oluştuğunu göstermektedir (Şekil 6).

Anketin 3. sorusunu "Eğitim durumunuz nedir?" sorusu oluşturmuştur. $\mathrm{Bu}$ sorunun cevabında ise ankete katılanların ağırlıklı olarak lise ve üniversitesi mezunlarından oluştuğu anlaşılmaktadır. Ankete katılanların 44'ü lise mezunu, 30'u üniversite mezunu, 26's1 ilkokul mezunu, 12'si ortaokul mezunu ve 3 kişi ise lisansüstü (yüksek lisans, doktora) mezunu kişilerden oluşmaktadır (Şekil 7). Bu durum göstermektedir ki köyden göç eden bireylerin ya da onların çocuklarının göç ettikleri yerlerde lise ve üniversite eğitim öğretimlerine devam ettikleri sonucuna varılmaktadır.

Anketin 4. sorusunu ankete katılanların "doğum yerlerinin neresi?" olduğu sorusu oluşturmaktadır. Toplamda 115 kişinin katıldığı ankette bu soruya Boyabat cevabı veren kişi sayısı 91dir. Bunu 21 kişi ile İstanbul, 2 kişi ile Ankara ve 1 kişi ile İzmit takip etmektedir (Şekil 8).

Ankete katılanların \%79’u Boyabat'ta dünyaya gelmiștir. Bu durum açıkça göstermektedir ki ankete katılanların büyük çoğunluğu

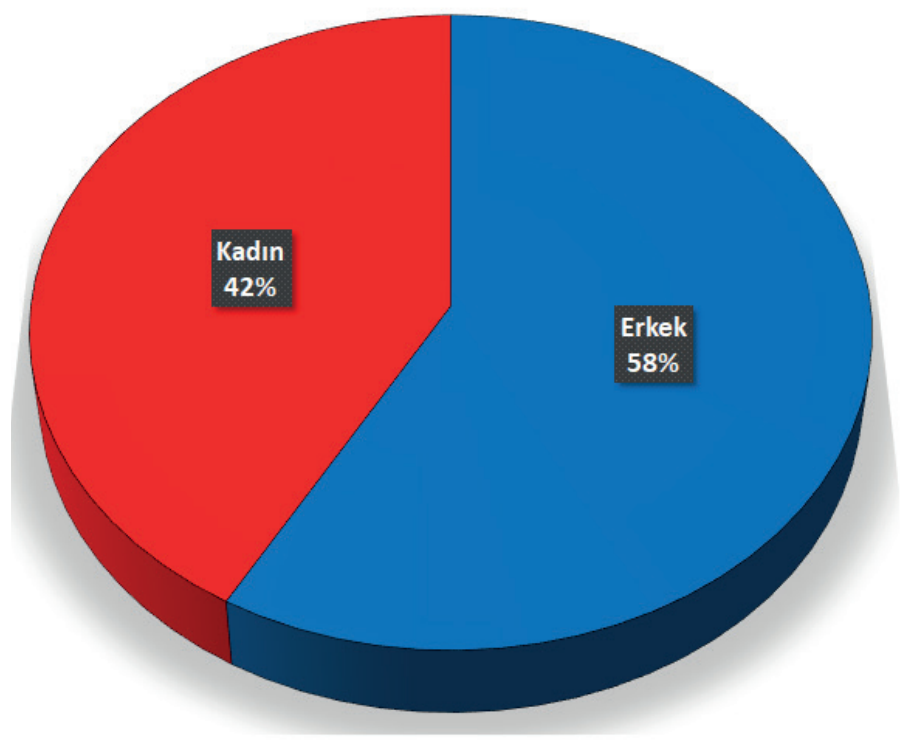

Şekil 6: Ankete Katılanların Cinsiyet Oranları. Figure 6: Gender Rates of Survey Participants.

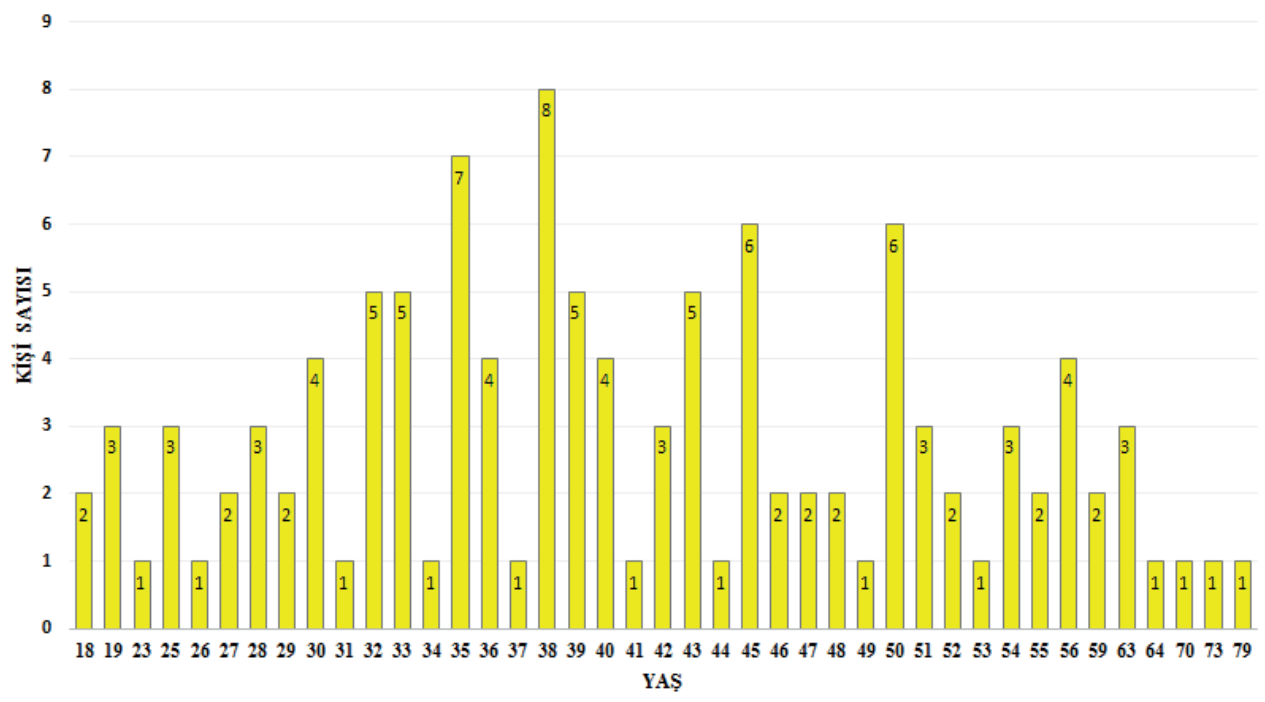

Şekil 5: Ankete Katılanların Yaşları.

Figure 5: Ages of Survey Participants. 


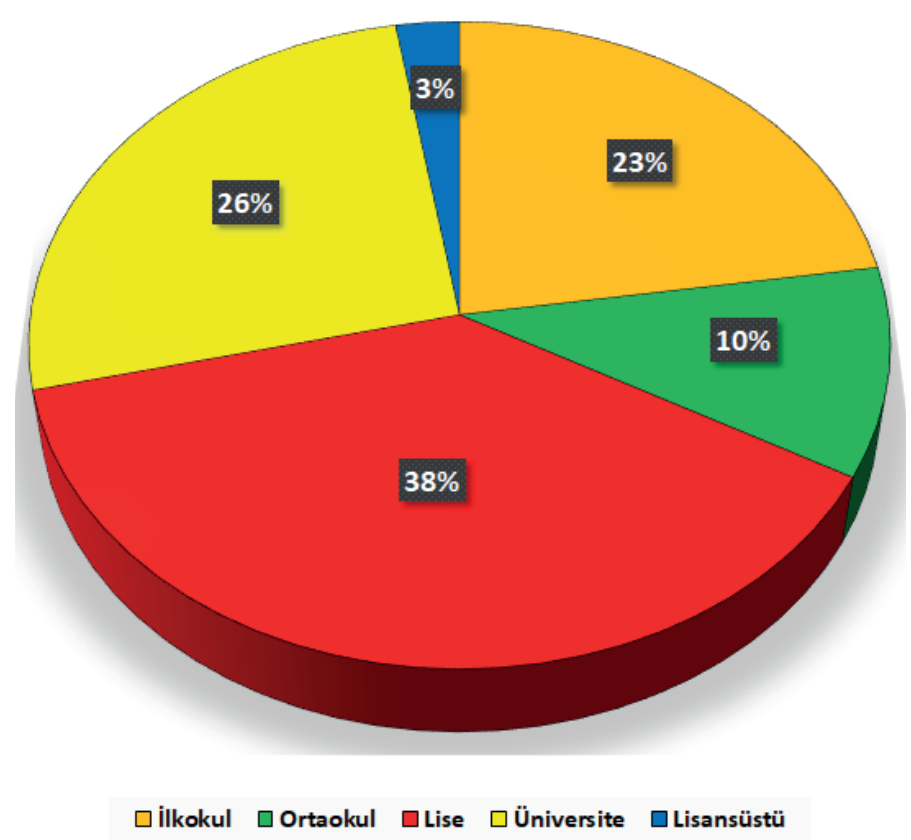

Şekil 7: Ankete Katılanların Eğitim Durumu. Figure 7: Education Status of Survey Participants.

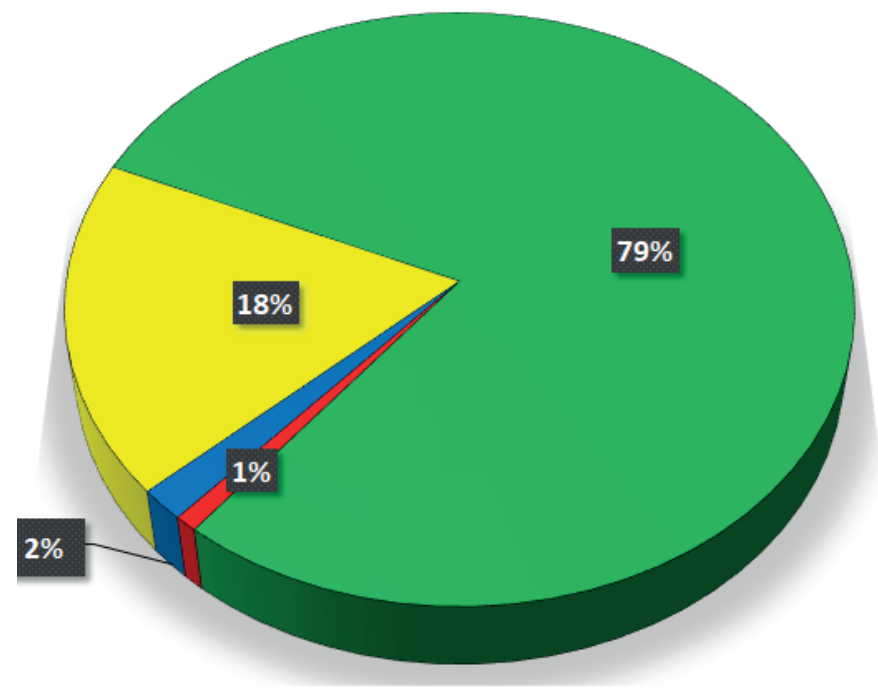

$\square$ İstanbul $\square$ Sinop Boyabat $\square$ İzmit $\square$ Ankara

Şekil 8: Ankete Katılanların Doğum Yerleri. Figure 8: Birth Place of Survey Participants.

köylerinde dünyaya gelmiş ve daha sonra göç etmişlerdir. Geri kalan \%21' lik kısım ise aileleri daha önce göç etmiş ve göç ettikleri yerlerde dünyaya gelmiş kişilerden oluşmaktadır.

Anketin 5. sorusu "Hangi yıl göç ettiniz?" dir. Genel olarak 1950 ile 2017 yılları arasında değişen göç yıllarından en fazla göç 12 kişi ile 1993 ve 11 kişi ile 1995 yıllarında verilmiştir. Özellikle 1970'li yıllara kadar daha çok 1 ve 2 kişi şeklinde gerçekleşen göçler özellikle 1980'liyıllardan sonra yoğunlaşmış ve 90'lı y1llarda en üst seviyelere çıkmıştır. 2000 yılından sonraköyün verdiği göç her ne kadar azalmış olsa da yine de köy göç vermeye devam etmiştir (Şekil 9). Çalışmada göç etme nedeni ayrı bir soru olarak sorulmuş ve yazının sonraki bölümlerinde yer verilmiştir.

Anketin 6. sorusunda "Hangi şehre gö̧̧ ettiniz?" sorusu yer almaktadır. Bu soruya ankete katılanların 94'ü İstanbul olarak cevap vermiştir. Aynı şekilde 8 kişi Ankara’ya, 4 kişi Kocaeli'ne, 3 kişi yurtdışına, 2 kişi İzmir ve Sinop'a 1 kişi ise Antalya ve Karabük illerine göç etmişlerdir (Şekil 10). Türkiye geneli için göç açısından bir cazibe merkezi olan İstanbul'un Bağlıca köyün için de benzer bir etki yarattığı görülmektedir.

Genel olarak kırsal alandan kentlere çok farklı nedenlerle göç hareketleri gerçekleşmektedir. Çalışma sahasında bu nedenleri ortaya koymak amaciyla anketin 7. sorusunda "Köyden göç etme nedeniniz nedir?" sorusu sorulmuştur. Bu soruda ankete katılanlara birden fazla seçenek işaretlemeleri imkânı sağlanmıştır.

Bağlica köyünden göç edenlerden 70'i ekonomik nedenlerden dolayı köyden göç ettiklerini belirtmişlerdir. $\mathrm{Bu}$ sonuç Türkiye genelinde kırdan kente göç nedenleri arasında ekonomik nedenlerin ilk sırada yer almasıyla örtüşen bir durumdur (Eren Yalçın ve Öcal Kara, 2016, s. 155). Bunu 22 kişi ile evlilik nedeniyle göç edenler takip etmiştir. Ankete katılan 115 kişiden 48'i kadındır ve bu kadınların neredeyse yarısı evlilik nedeniyle göç ettiğini söylemiştir. Özellikle 1970’li y1llarda başlayan ve yurtiçi göçler içerisinde göçü kolaylaştırıcı bir faktör olarak evlilik kurumunun kullanılması (Yılmaz, 2009, s. 223) eğilimi Bağlıca köyündeki kadınlarda da önemli bir faktör olmuştur. Aynı şekilde köylülerin köyden göç etme nedenlere arasında ailevi, sosyal ve hizmet eksikliği gibi nedenler de yer almaktadır (Şekil 11).

Anketin 8. sorusunu "Köyde kendinize ait bir eviniz var mı?" sorusu oluşturmaktadır. Ankete katılan kişilerden 88'i köyde kendisine ait bir evlerinin olduğunu, 27'si ise köyde kendilerine ait bir evinin olmadığını belirtmiştir (Şekil 12).

Anketin 9. sorusu "Köye ne siklikta gidiyorsunuz?"dur. Ankete katılanlardan 60’1 yılda iki kez köye gittiğini ifade etmiştir. Bunu 41 kişi ile yılda bir kez cevabı takip etmektedir. İki-üç yılda bir giderim diyenlerin sayısı 9, her ay giderim diyenlerin sayısı 5 iken, hiç gitmediğini belirtilen ise olmamıştır (Şekil 13). Bu durum göç edenlerin köyleri ile bağları oldukça güçlü olduğuna işaret etmektedir. 


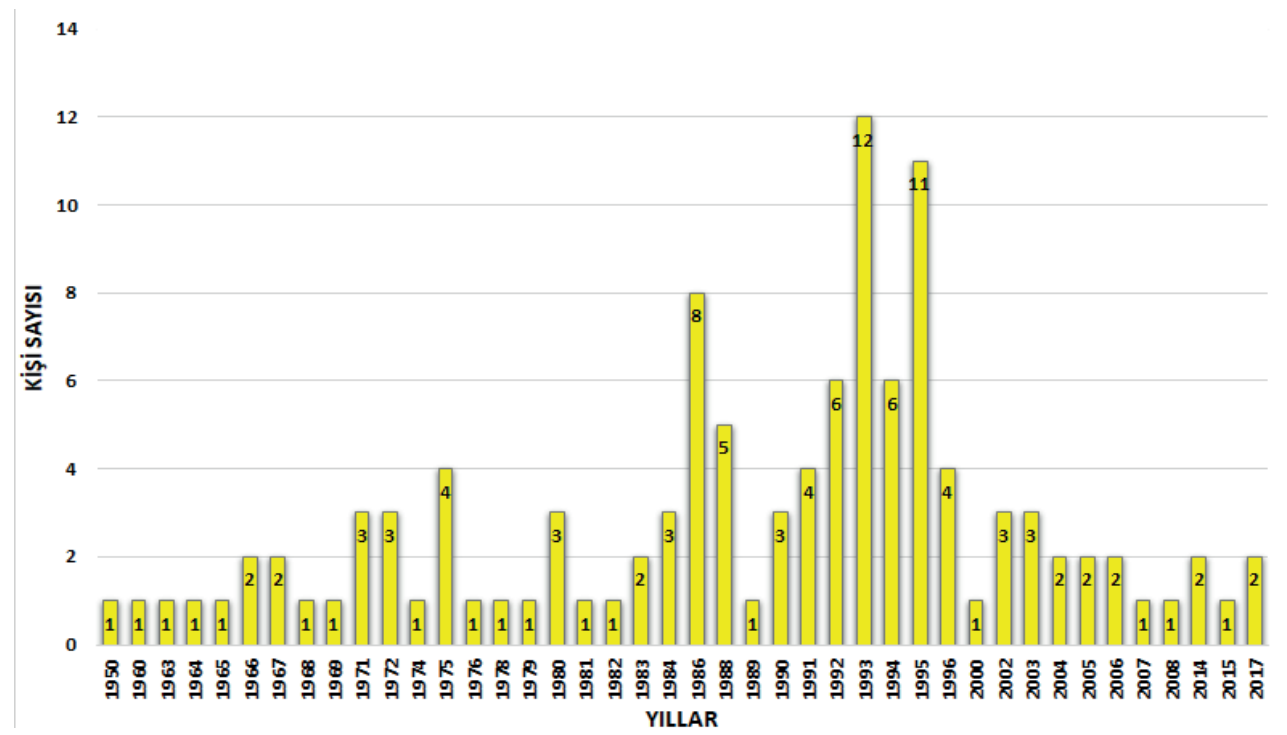

Şekil 9: Ankete Katılanların Göç Ettiği Yıllara Göre Dağılımı (1950-2017).

Figure 9: Distribution of Survey Participants by Years of Migration (1950-2017).

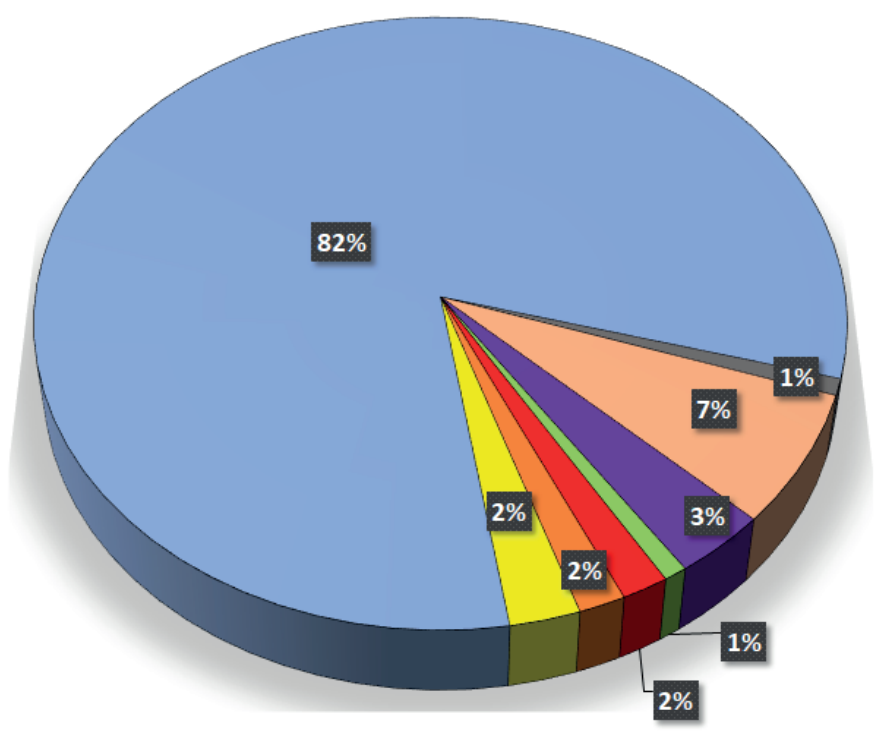

$\square$ İstanbul $\square$ Antalya $\square$ Ankara $\square$ Kocaeli $\square$ Karabük $\square$ Sinop $\square$ İzmir $\square$ Yurtdışı

Şekil 10: Ankete Katılanların Göç Ettikleri Şehirler.

Figure 10: Cities Migrated by Survey Participants.

Köyü ziyaret edenlerin yarısından fazlasının (\%52) yılda iki kez gittiklerini ifade etmeleri yaz tatillerini ve bayram tatillerini köylülerin köylerinde geçirdiğini göstermektedir. Bu durum göç eden köylülerin yeni kuşaklarının da köyü tanımasında, köy ile bağlarının güçlendirilmesinde etkin rol oynayacağını göstermektedir.

Anketin 10. sorusunda "Köye gittiğinizde ne kadar kallyorsunuz?" sorusu soruldu. Ankete katılanlardan 52'si 15 gün kaldığını, 39'u bir hafta kaldığını, 13'ü bir haftadan az

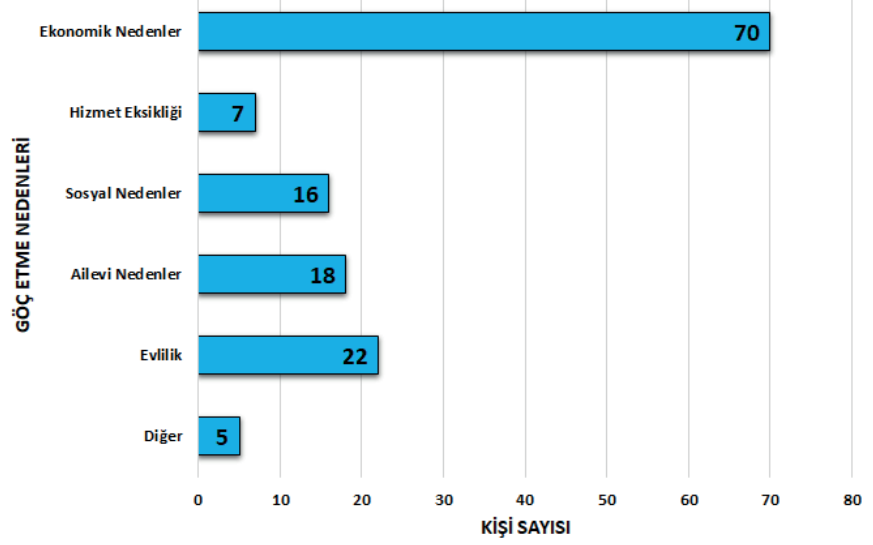

Şekil 11: Ankete Katılanların Köyden Göç Etme Nedenleri.

Figure 11: Reasons of Migration from the Village of Survey Participants.

kaldığını ve 11 'i ise 30 gün ve daha fazla kaldığını ifade etmiştir (Şekil 14). Bu durum köylülerin büyük çoğunluğunun yaz tatilini köyde geçirdikleri görüşünü desteklemektedir.

Anketin 11. sorusunda "Köye kendi isteğinizle mi gidiyorsunuz yoksa aileniz istediği için mi gidiyorsunuz?" sorusu sorulmuştur. Bu soruya 106 (\%92) kişi kendi isteği ile gittiğini, 9 (\%8) kişi ise ailesi istediği için gittiğini ifade etmiş̧ir. Daha önce de ifade edildiği üzere ankete katılanlar içinde köye hiç gitmediğini belirten kimse olmamıştır (Şekil 15). Bu sonuç 9. ve 10. sorunun sonuçlarını desteklediği gibi köylülerin köylerini ziyaretlerinde kendi isteklerinin daha etkili olduğunu göstermektedir.

Anketin 12. sorusunda "Köyü ziyaret etme sebebiniz nedir?" sorusuna cevap aranmıştır. Ankete katılanlar bu soruya birden 
fazla seçenek işaretlemişlerdir. Ankete katılan 115 kişiden 89'u bayram ve yaz tatillerini geçirmek için köyü ziyaret ettiklerini ifade etmiştir. Diğer taraftan 70 kişi aile ziyaretleri için, 48 kişi ise mezarlık ziyareti için köye gittiklerini belirtilmişlerdir. Bunu 26 kişi ile türbe ziyaretleri, 15 kişi ile panayır ve şenlik kutlamaları ve 17 kişi hasat yapmak için köye gittiklerini ifade etmiştir (Şekil 16).

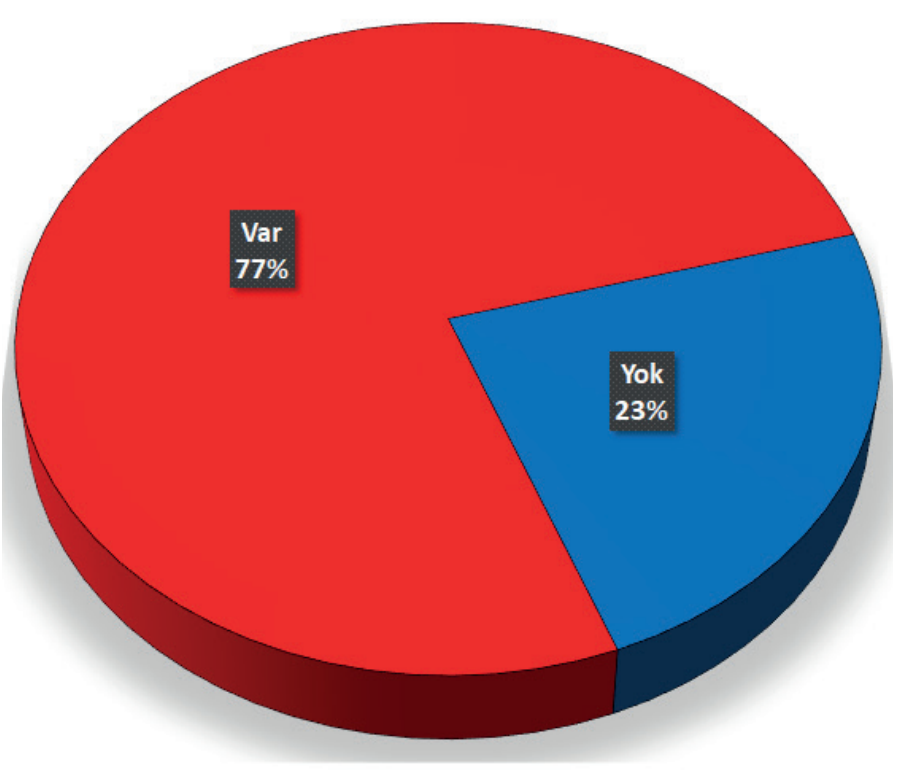

Şekil 12: Ankete Katılanların Köyde Ev Sahibi Olma Durumu. Figure 12: Status of the Host in the Village of Survey Participants.

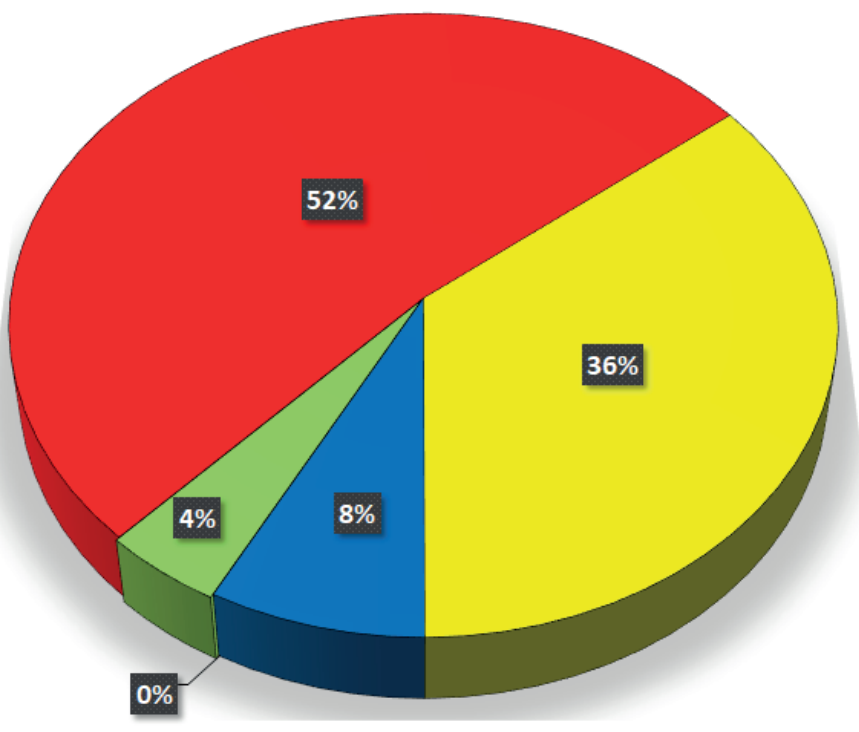

$\square$ Her ay $\square$ Yılda iki kez $\square$ Yılda bir kez $\square$ íki üçyılda bir $\square$ Hiç gitmem

Şekil 13: Ankete Katılanların Köyü Ziyaret Sıklıkları.

Figure 13: Frequency of Visits to Village of Survey Participants.
Anketin 13. sorusunda "İleride temelli olarak köye dönmeyi düşünür müsünüz?" sorusu sorulmuştur. 73 kişi bu soruya evet olarak cevap verirken, 15 kişi dönmek istemediğini belirtmiştir. 27 kişi ise kararsız olduğunu ifade etmiştir (Şekil 17). Bu sonuçlar göstermiştir ki ankete katılanların yazısından fazlası (\%64) ileride mutlaka köylerine dönmek istemektedirler.

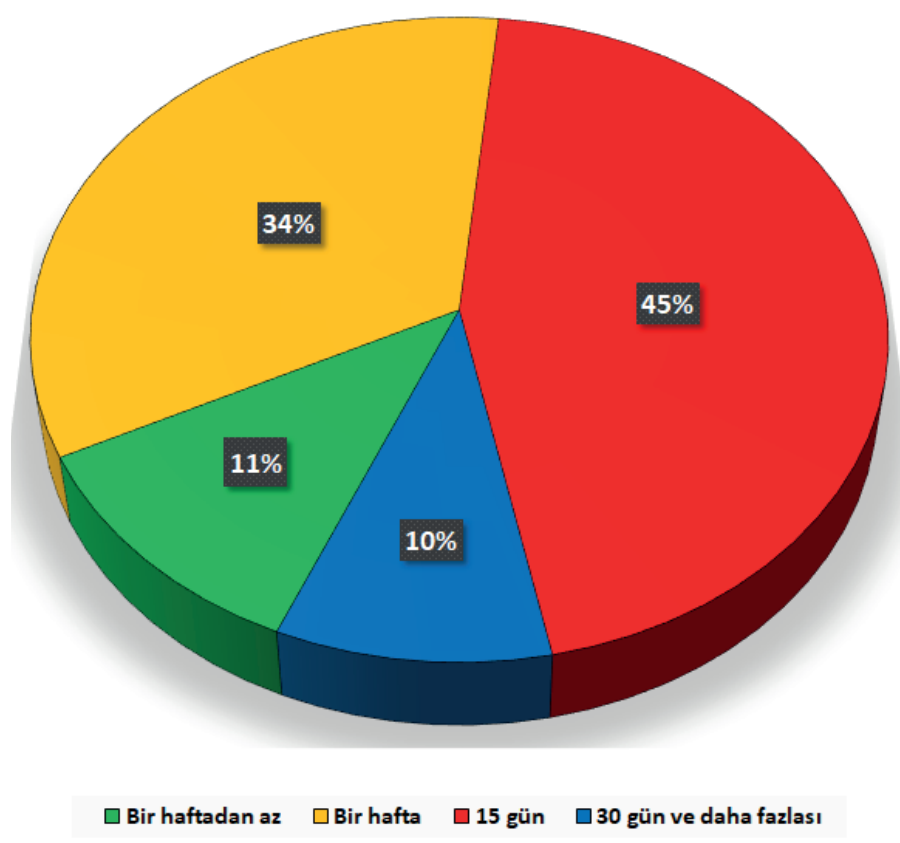

Şekil 14: Ankete Katılanların Köyde Kalış Süreleri.

Figure 14: Duration Stay in the Village of Survey Participants.

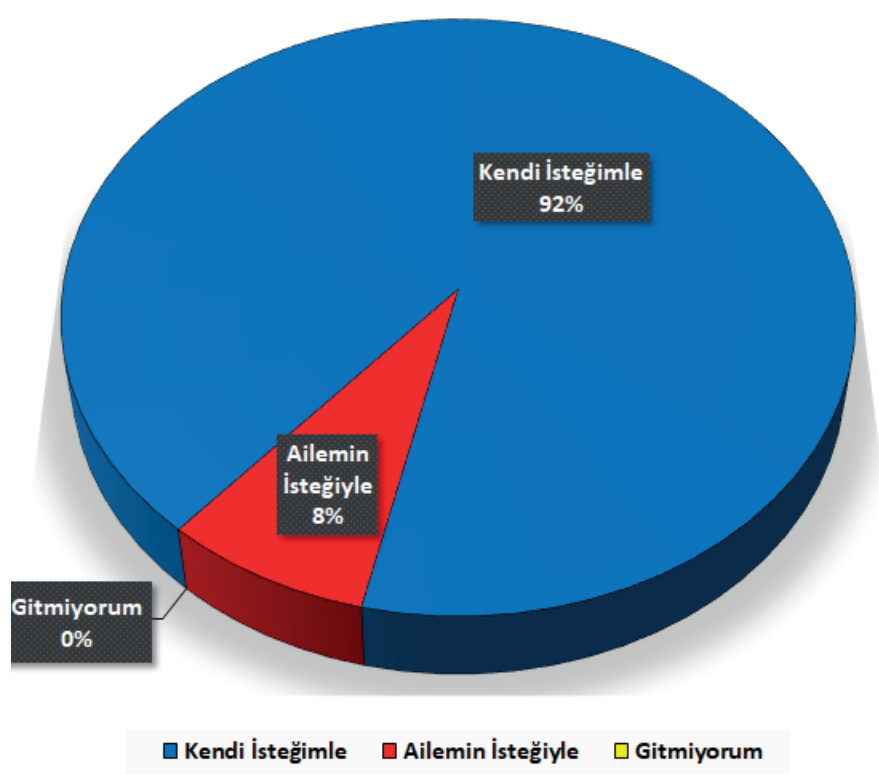

Şekil 15: Ankete Katılanların Köyü Ziyaret Etme İstekleri. Figure 15: Willingness to Visit the Village of Survey Participants. 


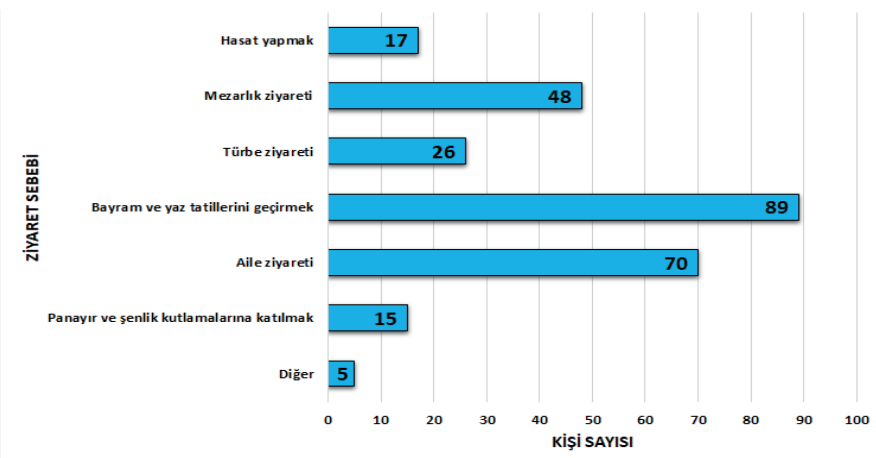

Şekil 16: Ankete Katılanların Köyü Ziyaret Sebepleri.

Figure 16: Reasons for Visiting the Village of Survey Participants.

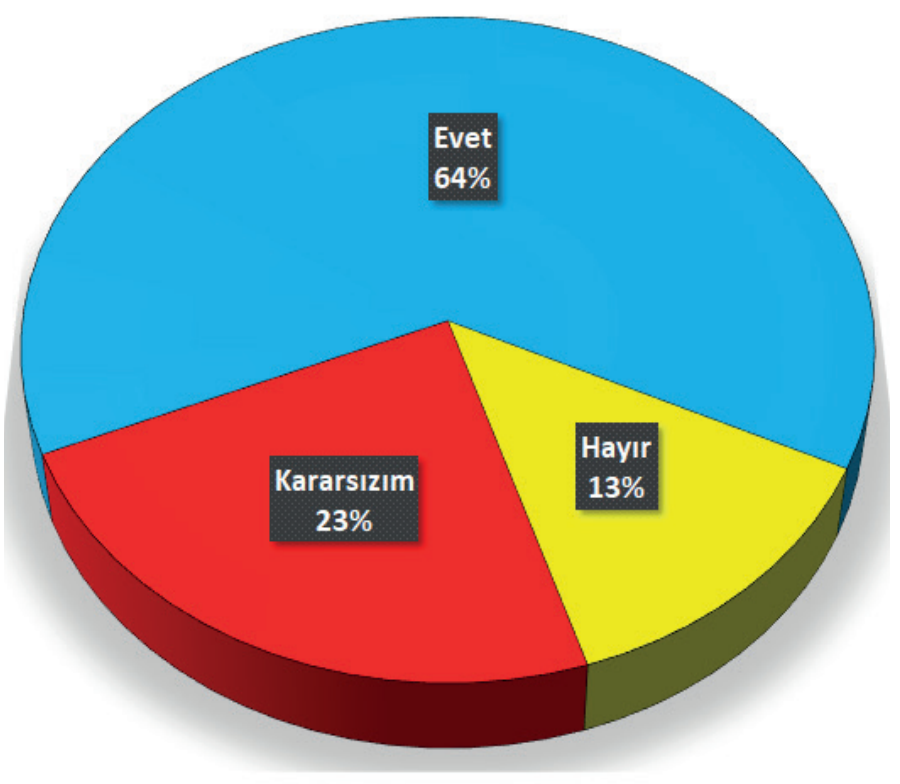

Şekil 17: Ankete Katılanların Köye Geri Dönme Düşünceleri. Figure 17: Opinions Returning to the Village of Survey Paticipants.

14. soruda ankete katılanlara "Köye ne zaman dönmeyi düşünürsünüz?" sorusu sorulmuştur. Bu soruya 51 kişi “emekli olunca dönmek isterim” şeklinde cevap vermiştir. 27 kişi “ekonomik şartlarım iyileşince”, 18 kişi “çocuklarım evlendikten sonra” köye dönmek istediklerini ifade etmişlerdir. Yine "köye dönmeyi düşünmüyorum” diyenlerin sayısı 15 olmuştur (Şekil 18).

Anketin 15. sorusunu "Ĕğer köye dönerseniz köyde hangi ekonomik faaliyeti yapmayı düşünürsünüz?" sorusu oluşturmaktadır. Bu soruya 13. soruda köye dönmeyi düşünenler cevap vermiştir ve toplamda 100 kişinin cevap verdiği bu soruda 52 kişi meyvecilik, 38 kişi ise tarım ve hayvancılık yapmak istediğini ifade etmiştir (Şekil 19). Diğeri içerisinde ise hobilerimi geliştirmek istiyorum diyenler, kendi mesleğini köyde yapmayı düşünüyorum diyenler en dikkat çekici cevaplardır.

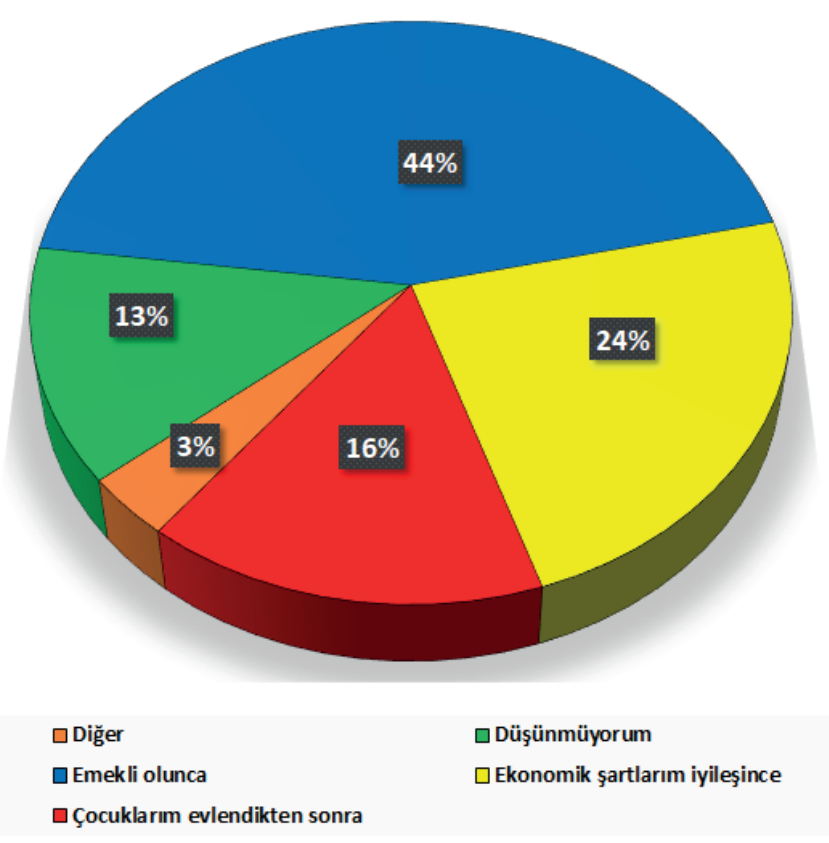

Şekil 18: Ankete Katılanların Köye Ne Zaman Dönmek İstedikleri. Figure 18: Time the Survey Participants Want to Return to the Village.

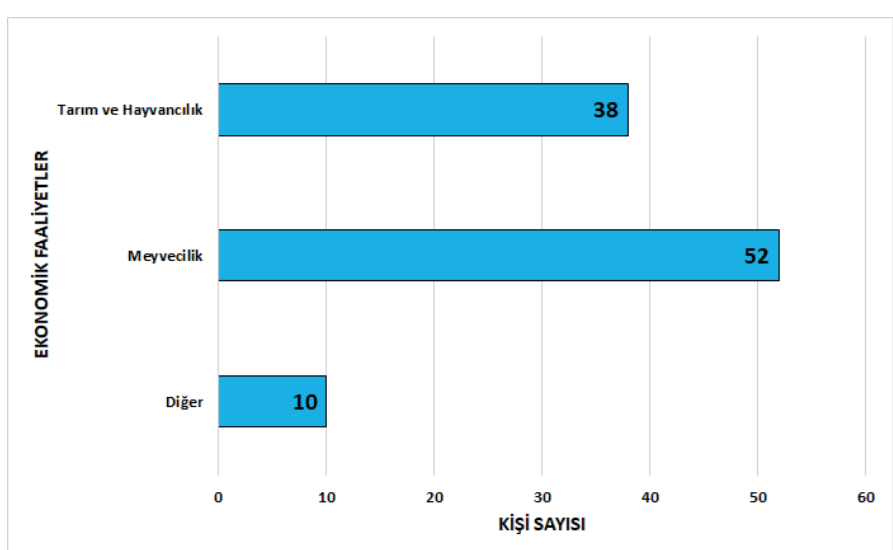

Şekil 19: Ankete Katılanların Köye Dönmesi Durumunda Yapmayı Düşündükleri Ekonomik Faaliyetler.

Figure 19: Economic Activities which the Survey Participants Plan to do in Case of Return to the Village.

Sonuç olarak, ankete katılan köylüler köyün genel geçim kaynağı olan çeltik tarımını meyvecilik faaliyetlerine göre daha az tercih ettikleri anlaşılmaktadır. Meyvecilik yapmayı tercih edenler ise daha çok ceviz, kavun ve karpuz yetiştiriciliği yapmak istediklerini ifade etmişlerdir.

16. soruyu "Çосuğunuzun köyünüzü tanımass ve kültürel değerlerinizi öğrenmesi için herhangi bir şey yapıyor musunuz?" sorusu oluşturmaktadır. Ankete katılanlar bu soruyu birden çok seçenek işaretleyerek cevaplamışlardır. Köylülerin çocuklarının köyü tanıması için en fazla tercih ettikleri yöntem vakit buldukça köye gitmek olmuştur. 66 kişi köylülerin düğünlerine katıldığını, 65 
kişi köy derneğinin yaptığı etkinliklere katıldığını, 63 kişi akraba ziyaretlerine önem verdiğini, 56 kişi ise cenaze törenlerine katıldığını ifade etmişlerdir (Şekil 20). Şehirlerde yaşayan köylülerin diğer köylülerle ilişkilerinin devamında ve kültürel değerlerini yaşatmada özellikle bu tarz etkinlikler büyük rol oynamaktadır.

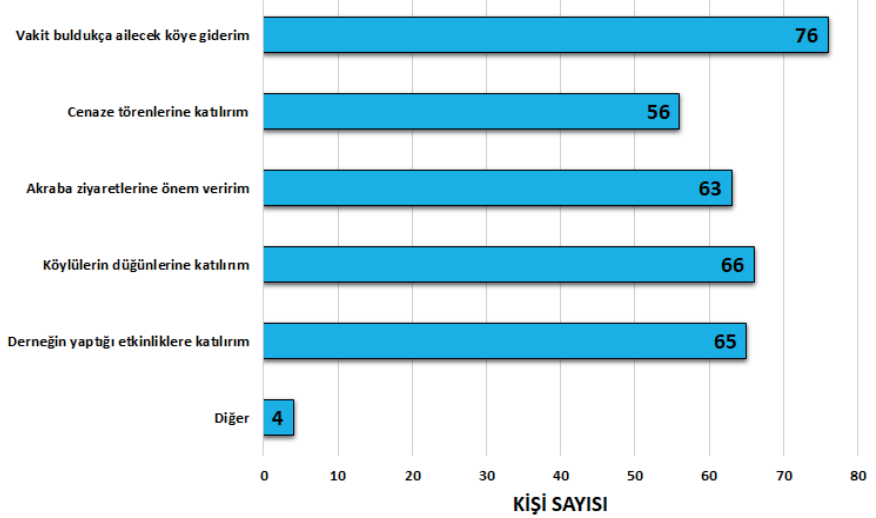

Şekil 20: Ankete Katılanların Çocuğunun Köyü Tanıması ve Kültürel Değerlerini Öğrenmesi İçin Yaptığı Şeyler.

Figure 20: The Activities That the Survey Participants do to Help Their Child Know the Village and Learn About Their Cultural Values.

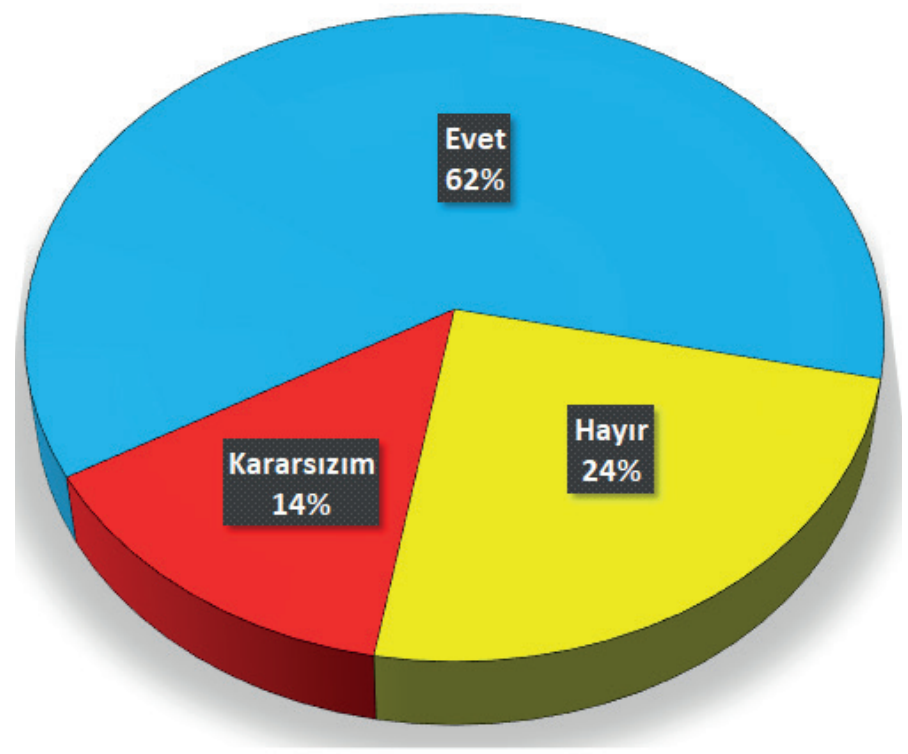

Şekil 21: Ankete Katılanların Çocuğunun Köye Dönmesini İsteme Durumları.

Figure 21: Status of the Survey Participants to Request That Their Child Return to the Village.

Anketin son sorusunu oluşturan 17. soruda "illeride çocuğunuzun köye dönmesini ister misiniz?" sorusu sorulmuştur. Bu soruya 71 kişi evet, 28 kişi hayır ve 16 kişi ise kararsızım cevabını vermiştir (Şekil 21). Bu sonuç göstermektedir ki, 13. soruda ileride köye dönmeyi düşünen 73 kişinin hemen hemen tamamı çocuğunun da köye dönmesini istemektedir.

\section{SONUÇ}

Kırsal alandan özellikle kentsel alanlara göçte ekonomik nedenler büyük ölçüde etkili olmaktadır. Ancak; köylerin geleneksel niteliklerle donatılmış ortamlarından uzaklaşmak, kentin sosyo-ekonomik ve fiziksel olanaklarından daha fazla yararlanmak ve güvenlik sorunları gibi başka birçok faktör bu nüfus hareketliliğinin yaşanmasına katkı sağlamaktadır.

Kırsal alanlardan şehirlere doğru göç eden nüfus gittikleri kentin mekânsal yapısını ve toplumsal oluşumunu etkilemekte ve ondan da etkilenmektedir. Diğer taraftan, ekonomik, sosyal, siyasal veya başka bir nedenden dolayı yeni yaşam sahalarına adapte olma durumuyla karşı karşıya kalsalar da, göçe konu olan insanların büyük bir bölümünün göç ettikleri yerler ile bağlarını tamamen koparmadığı görülmektedir. Bu topluluklar bir yandan şehirsel yaşamın akışına uyum sağlarken, diğer taraftan göç ettikleri yörelerin kültürünü de yaşatmanın çabası içinde olmaktadır. Sahip olduğu özgün kültürel değerlerini gelecek kuşaklara aktarmayı da hedefleyen bu çabalar, kimi zaman yaşadığ1 şehirde bazı faaliyetlerin yürütülmesi şeklinde biçimlenirken, çoğu kez köyünü ziyaret etmek şeklinde gerçekleşmektedir.

Bağlıca köylülerinden ankete katılanların \%52'si yılda $2 \mathrm{kez}$ köyünü ziyaret etmekte ve köye gittiklerinde genellikle 15 gün kalmaktadırlar. $\mathrm{Bu}$ durum köylülerin köyleri ile bağlarını koparmadığını, firsat buldukça köye gittiklerini göstermektedir. Ankete katılanların \%64'ü ilerleyen süreçte köylerine geri dönmeyi düşünmektedir. Bu durum gelecek dönemlerde köye daha fazla insanın kalıcı olarak dönebileceğine işaret etmektedir. Köye dönmeyi düşünen köylülerin $\% 62$ 'sinin çocuklarının da köye geri dönmesini temenni etmeleri sürecin sonraki nesiller için de devam edebileceğini düşündürmektedir.

Sonuç olarak; Geçmişten beri köylerden şehirlere doğru yaşanan yoğun göç ve bu göçün her iki alanda ortaya çıkardığg sonuçlar ilgi çekmekte ve analizlere konu olmaktadır. Günümüzde büyük ölçüde kısa süreli ziyaretler şeklinde gerçekleşen köy ile ilişkilerin gelecek dönemde farklı bir boyut kazanması muhtemeldir. Bağlıca köyü örneğinde olduğu gibi, gelecek dönemde farklı bir akışla bu kez şehirlerden köylere göçün ortaya çıkardığı yeni durumlar üzerinde durulması ve muhtemel sonuçların analiz edilmesi gerektiği düşünülmektedir.

Teşekkür: Anketin uygulanma aşamasında yardımlarını esirgemeyen Bağlıca Köyü Derneği Başkanı Sayın Kamber Battaloğlu'na ve ankete katılan köylülere çok teşekkür ederiz. 
Hakem Değerlendirmesi: Dıș bağımsız.

Çıkar Çatışması: Yazarlar çıkar çatışması bildirmemiştir.

Finansal Destek: Yazarlar bu çalışma için finansal destek almadığını beyan etmiştir.

Peer-review: Externally peer-reviewed.

Conflict of Interest: The authors have no conflict of interest to declare.

Grant Support: The authors declared that this study has received no financial support.

\section{KAYNAKÇA/REFERENCE}

Akkaş, İ. ve Sevim Y. (Ed.). (2017). Toplumsal entegrasyon bağlamında Erzincan'da yaşayan Ahıska Türkleri. Erzincan Üniversitesi Yayınları.

Akkayan, T. (1979). Göç ve değişme.İstanbul Üniversitesi Edebiyat Fakültesi Basımevi, İstanbul.

Aktaş, E., Aka, A. ve Demir, M. C. (2006). Türkiye'de hemşehri dernekleri ve kırsal dönüşüm. Tarım Ekonomisi Dergisi, 12, 51-58.

Çağlayan, S. (2015). Suriye savaşı ve Suriyeli göçmenler: teori ve kavramsal anlama çabası. Sosyoloji Divanı Dergisi, 3(6), 193-208.

DİE. (2000). Genel Nüfus Sayımları 1927-2000.

Doğanay, H. (1994). Türkiye beşeri coğrafyası. Gazi Büro Kitabevi, Ankara.

Dönmez Kara, C. Ö. (2015). Göç bağlamında uluslararası işbirliği ve Türkiye'nin politikaları. (Doktora Tezi). Çanakkale On Sekiz Mart Üniversitesi Sosyal Bilimler Enstitüsü, Çanakkale.

Eren Yalçın, G. ve Öcal Kara, F. (2016). Kırsal göç ve tarımsal üretime etkileri. Harran Tartm ve Gida Bilimleri Dergisi, 20(2), 154-158.

İslamoğlu, E., Yıldırımalp, S. ve Benli, A. (2014). Türkiye'de tersine göç ve tersine göçü teşvik eden uygulamalar: İstanbul ili örneği. Sakarya İktisat Dergisi, 3(1), 68-93.
Karakoyun, F. ve Kavak, M. T. (2008). WEB anketin yararları ve bir uygulama örneği olarak fizik tutum ölçeğine uygulanması. $D$. $\ddot{U}$. Ziya Gökalp Fakültesi Dergisi, 11, 129-141.

Kurt, H. (2006). Göç eğilimleri ve olası etkileri.Yönetim Bilimleri Dergisi, 4(1), 148-178.

Özer, İ.(2004). Kentleşme, kentlileşme ve kentsel değişme. Ekin Kitabevi: Bursa.

Sertkaya Doğan, Ö. (2019). Türkiye nüfus coğrafyası. N. Taşlıgil ve G. Şahin (Ed.) Türkiye Beşeri ve iktisadi coğrafyası kitabı içinde (s. 1-51). Nobel Yayın.

Sirkeci, İ. ve Cohen, J. H. (Ed.). (2015). Hareketlilik, göç, güvensizlik. Ankara: Kent Araştırmaları Enstitüsü,15, 8-21.

Toros, A. (2008).Sorunlu bölgelerde göç. Global Strateji Enstitüsü, Ankara.

Taş, Y. ve Özcan, S. (2013). Türkiye'de iç göçün yoksulluğa ve istihdama etkileri.SESSION 1B: büyüme ve gelişme, Erişim adresi:https://www.avekon.org/papers/609.pdf.

Tekeli, İ. ve Erder, L. (1978). Yerleşme yapısının uyum süreci olarak iç göçler.Hacettepe Üniversitesi Yayınları, Ankara.

TUİK. (2018). Adrese Dayalı Nüfus Kayıt Sistemi 2007-2018,Erişim adresi: https://biruni.tuik.gov.tr/medas/?kn=95\&locale=tr.

Tümertekin, E. ve Özgüç, N. (2011). Beşeri coğrafya: insan-kültürmekan (12.bs). Çantay Kitabevi, İstanbul

Yazıcı, H. (2012). Münif Paşa'da tersine göç olgusu. Ístanbul Üniversitesi Şarkiyat Mecmuası, 20(1), 103-113.

Yılmaz, C. (2009). Türkiye'de kırdan kente göç sürecinde etkili olan faktörlerden biri; evlilik yoluyla göç. Doğu Coğrafya Dergisi, 14(21), 221-232.

Yürüdür, E. (2008). Koyulhisar İlçesinde (Sivas) göç hareketleri. Doğu Coğrafya Dergisi, 13(20), 19-34. 